\title{
Penerapan Ensemble Stacking untuk Peramalan Laba Bersih Bank Syariah Indonesia (BSI)
}

\author{
Nurfia Oktaviani Syamsiah", Indah Purwandani \\ Fakultas Teknik dan Informatika, Sistem Informasi Akuntansi, Universitas Bina Sarana Informatika, Pontianak, Indonesia \\ Email: ${ }^{1}$ nurfia.nos@bsi.ac.id, ${ }^{2}$,indah@bsi.ac.id \\ Email Penulis Korespondensi: nurfia.nos@bsi.ac.id \\ Submitted: 12/12/2021; Accepted: 27/12/2021; Published: 31/12/2021
}

\begin{abstract}
Abstrak-Prediksi data univariate telah dilakukan oleh banyak peneliti dengan beragam metode yang digunakan. Penelitian tersebut dilakukan dengna menggunakan satu metode, membandingkan beberapa metode hingga menggabungkan beberapa metode. Dalam penelitian ini menggunakan beberapa metode dan juga sekaligus menggabungkan beberapa metode. Metode tersebut adalah dengan penerapan Ensemble, yakni Stacking. Sedangkan data univariate yang digunakan adalah Data Laba Bulanan Bank Syariah Indonesia. Adapun penelitian ini bertujuan untuk membuktikan keakuratan hasil prediksi ensemble stacking dengan menerapkan algoritma SVM, Random Forest, Neural Network dan General Linier Model. Berdasarakan hasil penelitian didapatkan bahwa dengan menerapkan Stacking didapatkan hasil yang paling akurat untuk memprediksi data runtun waktu univariat (laba Bank Syariah Indonesia), dimana RMSE yang dihasilkan adalah 0,534.
\end{abstract}

Kata Kunci: Univariate; Ensemble; Stacking; Neural Network; SVM; Random Forest

\begin{abstract}
Univariate data prediction has been done by many researchers with various methods used. The research was conducted using one method, several methods to combine several methods. This research uses several methods and simultaneously combines several methods. The method is by applying the Ensemble, namely Stacking. Meanwhile, the univariate data used is the Indonesian Sharia Bank Monthly Profit Data. This study aims to prove the accuracy of ensemble stacking prediction results by applying the SVM, Random Forest, Neural Network, and General Linear Model algorithms. Based on the results of the study, it was found that by applying Stacking the most accurate results were obtained for predicting univariate time series data (Indonesian Islamic Bank profits), where the RMSE generated was 0.534 .
\end{abstract}

Keywords: Univariate; Ensemble; Stacking; Neural Network; SVM; Random Forest

\section{PENDAHULUAN}

Peramalan menjadi sebuah kegiatan yang tidak terpisahkan dari kehidupan manusia. Di setiap kegiatan, peramalan telah menjadi sebuah rutinitas yang dilakukan baik oleh perorangan, organisasi maupun oleh industri. Bagian apapun di semua sektor memiliki keterlibatan dalam perencanaan guna mencapai efisiensi alokasi sumber daya [1]. Secara sederhana peramalan merupakan upaya memperkirakan kemungkinan peristiwa yang mungkin terjadi selama beberapa jangka waktu. Menurut [2] peramalan adalah tentang upaya memprediksi masa depan seakurat mungkin, mengingat semua informasi yang tersedia, dengan menggunakan data historis dan pengetahuan tentang masa depan ataupun segala peristiwa yang mungkin akan mempengaruhi peramalan. Peramalan juga dapat diartikan sebagai sebuah cara untuk mendapatkan interval berdasarkan data saat ini dan masa lalu dimana pada umumnya bertujuan untuk mengetahui tren masa depan. Hasil peramalan biasanya diterapkan untuk membantu proses pengambilan keputusan, perencanaan, dan alokasi sumber daya [3].

Tujuan dari peramalan berdasarkan rentang waktu dapat terbagi menjadi empat tingkatan. Tingkatan yang pertama disebut peramalan strategis, yakni peramalan dengan rentang waktu minimal 1 tahun. Tingkat kedua adalah peramalan taktis, rentang waktunya adalah 3 bulan hingga 1 tahun atau lebih dan biasanya diterapkan pada perencanaan operasional ataupun kegiatan pengendalian. Peramalan operasional adalah tingkatan peramalan berikutnya. Tingkat ini biasanya berlangsung setidaknya selama satu tahun ke depan dan muncul dalam kerangka waktu mingguan. Hasil dari peramalan level ini akan digunakan untuk penjadwalan. Tingkatan terakhir adalah peramalan immediate, yang digunakan untuk menentukan kinerja sehari-hari dari aktivitas yang sedang berlangsung [4]. Beberapa penelitian tentang peramalan tersebut misalnya peramalan dalam hal energi kelistrikan [5][6][7], tentang kesehatan [8] [9], penjualan [4] [10], meteorologi [11] dan masih banyak bidang lainnya.

Peramalan deret waktu telah menjadi sebuah sub bidang penelitian di beberapa dekade ini, kondisi tersebut diikuti dengan berbagai model statistik dan algoritma komputasi canggih yang telah dikembangkan untuk meningkatkan akurasinya. Keberadaan metode-metode baru peramalan tentunya memberikan lebih banyak pilihan. Namun, dalam praktiknya dapat menimbulkan permasalahan potensial lainnya, seperti sedikitnya tingkat pemahaman tentang mengapa metode peramalan tertentu berkinerja baik. Oleh karena itu, dalam konteks peramalan, aturan rekomendasi tentang cara memilih metode peramalan yang sesuai untuk jenis deret waktu tertentu menjadi sebuah hal yang sangat menarik untuk diteliti lebih lanjut [12]. Pada dasarnya data deret waktu memiliki karakteristik unik seperti jumlah data yang besar, adanya noise secara acak, dan hubungan non linier pada elemen data. Jenis data ini dihasilkan secara kronologis dan memiliki karakteristik berdimensi tinggi dengan ketergantungan temporal. Yang dimaksud dimensi tinggi disini adalah bahwasanya setiap titik waktu akan menjadi sebuah dimensi, dan ketergantungan temporal berarti jika dua titik yang identik secara numerik bisa saja termasuk dalam kelas yang berbeda atau dapat memprediksi perilaku yang berbeda. Menurut jumlah variabel sampling pada titik waktu, deret waktu dapat dibagi menjadi deret 
waktu univariat dan deret waktu multivariat [13]. Deret waktu univariat hanya satu variabel yang diamati sedangkan multivariat terdapat lebih dari satu variable [14].

Terdapat dua kubu dalam peramalan, yakni kubu metode Statistik dan kubu metode Machine Learning. Tentunya kedua metode ini memiliki tujuan yang sama, yakni untuk meningkatkan akurasi peramalan dengan meminimalkan nilai kesalahan. Sedangkan perbedaan yang ditemukan adalah metode ML menggunakan algoritma non-linear sedangkan statistik menangani proses linier [15]. Ketika tujuan peramalan hanya sebatas untuk mengurangi nilai kesalahan, maka pendekatan ML akan lebih tepat digunakan. Sedangkan statistik memiliki keunggulan dalam memberikan hasil peramalan yang lebih tepat, namun memerlukan pengetahuan atas domain data dan teknik komputasi yang lebih besar untuk memilih parameter terbaiknya [16].

Khusus pada penelitian di bidang peramalan runtun waktu, sebagian besarnya menghasilkan kesimpulan bahwa menggabungkan beberapa metode akan meningkatkan akurasi dibandingkan hanya mengguankan satu metode saja. Metode yang digunakan dengan cara menggabungkan beberapa metode inilah yang disebut dengan ensemble [17]. Metode ensemble menggabungkan beberapa model supervised learning menjadi sebuah "supermodel". Tujuan penggunaan ensemble adalah untuk meningkatkan kekuatan sebuah model agar menghasilkan kinerja terbaik ketika digabungkan dengan model lainnya sehingga mencapai akurasi prediksi yang lebih baik [18].

Beberapa metode ensemble yang dilakukan antara lain dengan melakukan perubahan pada satu atau beberapa hal di suatu metode seperti mempartisi kumpulan data berdasarkan fitur temporal [6], menggabungkan output perbandingan beberapa metode untuk membentuk prediksi akhir dari variabel target [9], menggunakan bobot yang lebih dinamis [19], ataupun menggunakan gabungan beberapa metode seperti radial basis function neural networks (RBFNN) dan generalized regression neural networks (GRNN) [20], bagging dan boosting [18][21] serta ada pula yang menggunakan stacking [22] [23][24]. Semua metode tersebut menghasilkan kesimpulan serupa, yakni penerapan ensemble menghasilkan akurasi yang lebih baik dari pada yang hanya menerapkan satu metode saja.

Penelitian ini akan menggunakan algoritma stacking yang merupakan metode ensemble yang telah terbukti mencapai akurasi prediksi yang lebih tinggi dan mampu mengurangi kesalahan generalisasi. Ide umum dari Stacking adalah untuk menggabungkan hasil dari prediksi beberapa algoritma dasar untuk selanjutnya digunakan oleh algoritma level atasnya untuk menghasilkan prediksi yang lebih baik lagi. Stacking memiliki kemampuan untuk melampaui beberapa model ensemble dan telah digunakan secara bertahap oleh beberapa peneliti lainnya [23] [25] [26].

Penelitian ini akan membandingkan hasil peramalan laba bersih Bank Syariah Indonesia. Sebelumnya penelitian serupa pernah juga dilakukan, namun hanya menggunakan Neural Network [27]. Sedangkan pada penelitian ini akan menerapkan ensemble stacking menggunakan 4 algoritma dasar yakni SVM, NN, Random Forest dan Generalized Linier Model (GLM). Metode Stacking merupakan metode yang telah banyak digunakan pada penelitianpenelitian sebelumnya, namun belum ada yang menerapkannya untuk peramalan data keuangan khususnya laba bersih suatu perusahaan. Penerapan Stacking dilakukan dengan membangun model menggunakan beberapa algoritma yang berbeda tersebut kemudian algoritma penggabung yakni GLM dilatih untuk membuat prediksi akhir menggunakan prediksi yang dihasilkan oleh algoritma dasar.

Laba bersih merupakan indikator ekonomi yang penting. Bagi investor, laba bersih merupakan faktor dasar untuk mendapatkan pengembalian investasi. Bagi para manajer, laba bersih merupakan dasar pengambilan keputusan manajemen. Perbankan Syariah telah menjadi solusi pertumbuhan ekonomi bangsa. Bank Syariah Indonesia merupakan penggabungan beberapa Bank Syariah milik pemerintah yang telah resmi dilakukan per tahun 2021 ini, yaitu Bank Syariah Mandiri (BSM), Bank Negara Indonesia Syariah (BNIS) dan Bank Rakyat Indonesia Syariah (BRIS) [28].

Terdapat banyak faktor yang dapat mempengaruhi perolehan laba bersih, seperti laba atas ekuitas, rasio kas, dan rasio kekhasan bisnis. Peramalan laba bersih merupakan bentuk peramalan regresi multi dimensi. Telah banyak penelitian tentang peramalan laba bersih yang mengunakan metode tradisional yakni dengan perhitungan manual, estimasi perseptual dan lain sebagainya. Metode ini dianggap kurang up to date, pengolahan datanya tidak efisien serta akurasi peramalan yang masih dianggap kurang akurat [29].

Penelitian ini berupaya membuktikan bahwa penerapan metode stacking mampu memberikan hasil prediksi laba Bank Syariah Indonesia dengan akurasi yang paling tinggi.

\section{METODOLOGI PENELITIAN}

Berdasarkan beberapa penelitian dinyatakan bahwasanya pendekatan algoritma machine learning memberikan solusi efektif untuk peramalan deret waktu, namun terdapat kecenderungan untuk terjebak dalam kondisi lokal optimal. Untuk menyelesaikan permasalahan tersebutlah maka pada penelitian ini peramalan dilakukan dengan menerapkan metode ensemble.

Berbeda dengan pendekatan biasa, yang mencoba mempelajari satu hipotesis dari data pelatihan, metode ensemble mencoba membangun serangkaian hipotesis dan menggabungkannya. Pendekatan ini biasanya menghasilkan hasil yang lebih baik daripada pendekatan tunggal, karena memberikan generalisasi yang lebih baik, kemampuan yang lebih baik untuk mencegah kondisi lokal optimal dan kemampuan pencarian yang lebih unggul.

Dalam penelitian ini, diusulkan sebuah skema ensemble baru, dengan menggunakan dua lapisan. Pada lapisan pertama akan menggunakan tiga algoritma pembelajaran yang dimana hasil prediksi tersebut akan digunakan oleh 
algoritma lain di lapisan lainnya. Adapun tiga algoritma pertama adalah SVM, Random Forest dan Neural Network. Sedangkan Generalized Linier Model digunakan di lapisan selanjutnya.

Data yang digunakan dalam penelitian ini adalah data laba bersih Bank Syariah Indonesia dari rentang waktu Januari 2002 hingga Mei 2021 yang berbentuk data runtun waktu univariat bulanan. Walaupun pada beberapa penelitian dihasilkan akurasi yang lebih baik jika menggunakan data multivariate, namun deret waktu multivariat hampir tidak dapat mengekstrak informasi komponen yang bermanfaat untuk proses peramalan [30]. Selain itu perluasan rentang waktu yang digunakan yakni dari harian ke bulanan akan semakin meningkatkan nilai akurasi peramalan [31]. Sudut pandang inilah yang menjadi alasan mengapa pada penelitian ini menggunakan runtun waktu univariate bulanan.

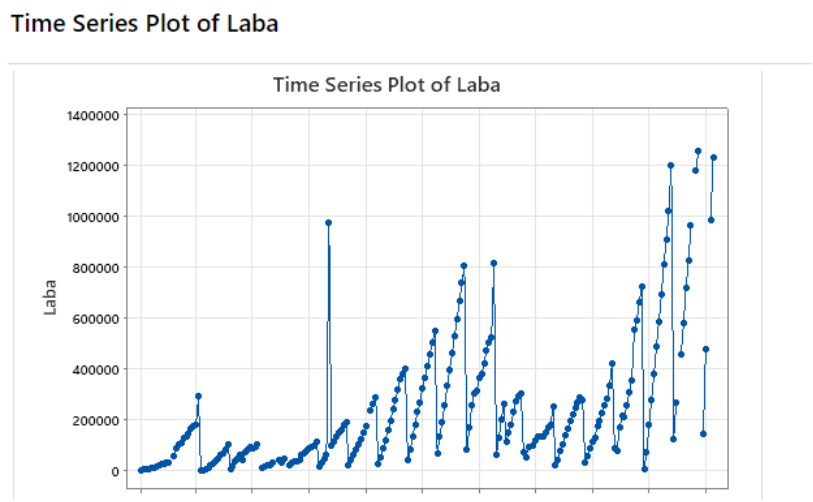

Gambar 1. Visualisasi Data Set Laba BSI

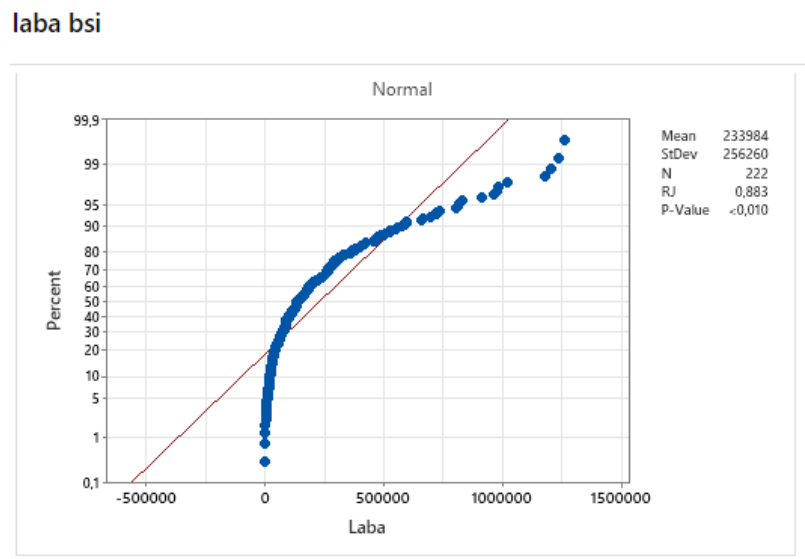

Gambar 2. Hasil Pemeriksaan Normalisasi Data Laba BSI

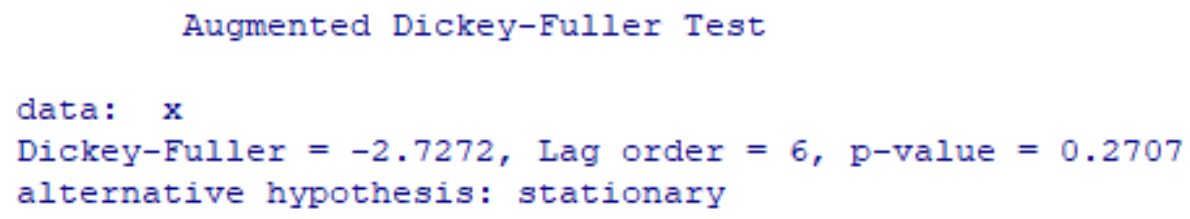

Gambar 3. Hasil ADF Test Data Laba BSI

Berdasarkan gambar 1 terlihat bahwa data laba BSI bersifat non stasioner sehingga perlu dilakukan transformasi data. Namun analisis visual dianggap belum cukup untuk menyatakan stasioner atau tidaknya suatu plot data, maka dalam penelitian ini dilakukan juga proses uji stasioner. Yang digunakan adalah metode Augmented Dickey-Fuller Test. Dengan menerapkan Hipotesis berikut ini:

H0 : data deret waktu tidak stasioner (unit root mendekati 1)

H1 : data deret waktu stasioner (unit root tidak mendekati 1) $\alpha=5 \%$

Berdasarkan gambar3 didapatkan p-value lebih besar dari $\alpha$ sehingga diputuskan untuk menerima H0, yakni data tidak stasioner. Agar bisa diketahui lebih lanjut apakah data belum stasioner pada varians ataukah pada rata-rata (mean), maka dilakukan uji Box Cox dan Difference. 


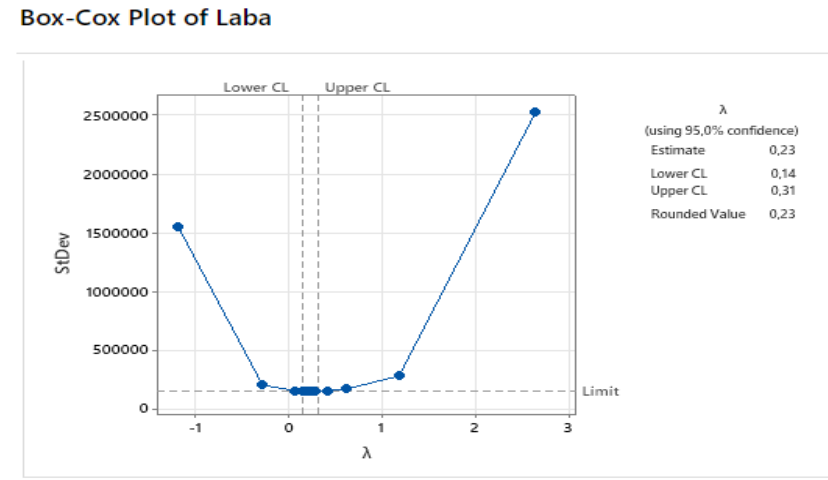

Gambar 4. Hasil Box-Cox Laba BSI

Berdasarkan gambar 4 terlihat hubungan lambda dengan standar deviasi. Lower CL dan Upper CL 0,14 sampai 0,31 nilai lambda terbaik adalah 0,23. Data hasil Box-Cox kemudian dilakkan uji normalitas, dan dihasilkan data baru yang hasil plotnya terlihat pada gambar 5.

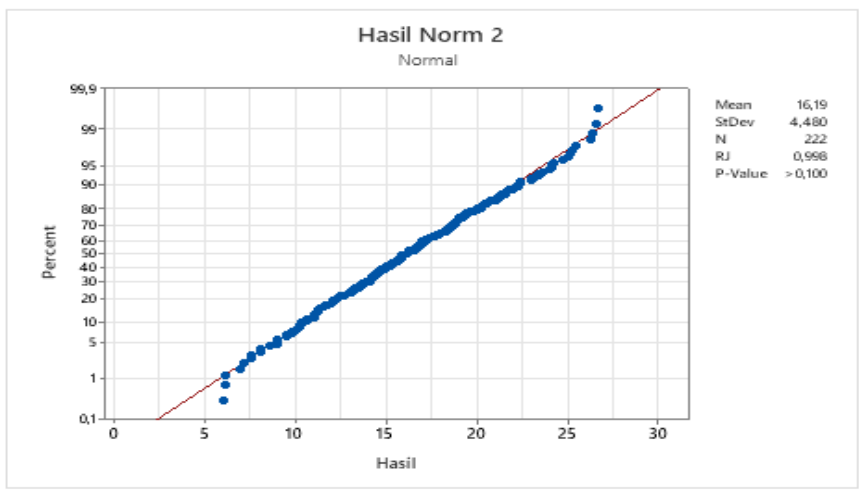

Gambar 5. Plot data Box-Cox yang dinormalisasi

Berdasarkan Gambar 5 terlihat data berada di sekitar garis lurus. Ada perubahan juga pada Nilai P Value, dimana saat ini sudah $>0,100$ sehingga disimpulkan data hasil transformasi sudah menjadi normal. Data ini yang akan digunakan untuk proses selanjutnya.

Seperti yang sudah dipaparkan di bagian sebelumnya, bahwa penelitian ini menggunakan pendekatan stacking, karena berdasarakan kajian terdahulu yang telah dibahas sebelumnya didapatkan bahwa pendekatan ini lebih cocok dan menghasilkan akurasi yang lebih baik dibandingkan pendekatan lainnya. Skema ini dibentuk oleh empat metode, yakni Jaringan Syaraf Tiruan, Suport Vector Machine, Random Forest dan General Linier Model. Di level atas, model General Linier Model digunakan untuk menggabungkan prediksi yang dihasilkan oleh tiga metode di tingkat bawah.

Definisi skema ensemble stacking secara formal adalah seperti penjelasan berikut:

Satu set $\mathrm{N}$ algoritma pembelajaran yang berbeda $L_{k}, \mathrm{k}=1, \ldots, \mathrm{N}$ pasangan $\langle\mathrm{x}, \mathrm{y}\rangle$, dengan $\mathrm{x}=\left(X_{1}, . ., X_{w}\right)$ mewakili nilai yang direkam w dan $\mathrm{y}=\left(X_{w}+1, . ., X_{w}+\mathrm{h}\right)$, nilai h untuk diprediksi.

Misalkan $M_{k j}, \mathrm{k}=1, \ldots, \mathrm{N}, \mathrm{j}=1, \ldots, \mathrm{h}$, adalah model yang diinduksi oleh algoritma pembelajaran $L_{k}$ pada $\mathrm{x}$ untuk memprediksi $X_{w j}$, dan misalkan $f_{j}$ adalah fungsi generalisasi yang bertanggung jawab untuk menggabungkan model untuk memprediksi nilai tersebut. $f_{j}$ dapat berupa fungsi generik, seperti rata-rata, atau model yang diinduksi oleh algoritma pembelajaran. Kemudian, nilai taksiran $X_{w j}$ diberikan oleh ekspresi:

$$
X_{w+j}=f_{j}\left(m_{1 j}, \ldots, m_{N j}\right)
$$

Adapun tahapan yang akan dilakukan dapat terlihat pada gambar 1.

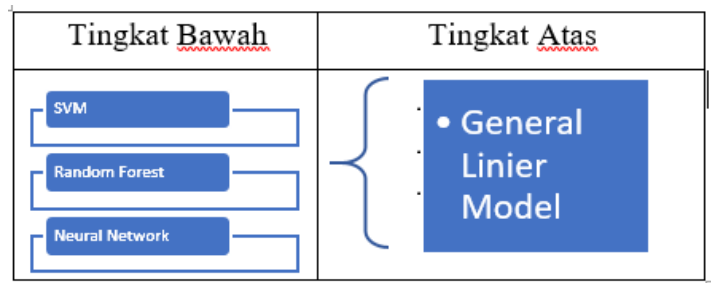

Gambar 6. Tahapan Stacking Yang Diusulkan 
Performa algoritma data runtun waktu tertentu dapat dipengaruhi oleh banyak faktor, dua factor terpentingnya adalah kualitas data latih dan fitur input. Selain itu data biasanya dikumpulkan dengan beberapa metode pengumpulan data, yang seringkali tidak terpantau dengan baik. Oleh karena itu, seringkali banyak jenis informasi yang tidak relevan dan berlebihan dalam data set asli, seperti nilai di luar rentang, kombinasi data yang tidak mungkin, dan nilai yang hilang. Kemudian algoritma pembelajaran mesin sulit untuk menganalisis data yang belum disaring dengan hati-hati, dan akhirnya menunjukan hasil yang menyesatkan. Untuk itulah dilakukan Pra-pemrosesan data, yang secara umum terdiri dari pembersihan data, normalisasi, ekstraksi fitur dan pemilihan, dll.

Dalam penelitian ini data laba BSI yang digunakan adalah data publik namun data ini termasuk ke dalam kategori yang terkontrol dengan sangat baik, karena setiap nilai yang disampaikan telah memalui proses penanganan OJK. Berdasarkan analisis terlihat bahwasanya di beberapa bulan tertentu di setiap tahun ada data laba yang memang tidak terisi, dan hal ini pun telah disampaikan secara publik di website. Untuk itu pembersihan data yang akan dilakukan adalah mengatasi data kosong (Remove Missing Value) saja. Sedangkan untuk normalisasi data yang digunakan adalah dengan Z-Score. Dimana metode ini menjadi metode normalisasi yang dianggap paling terbaik dibandingkan metode-metode lainnya. Proses ekstraksi fitur tidak dilakukan, namun dalam penelitian ini dilakukan proses windowing data dengan menggunakan 12 window.

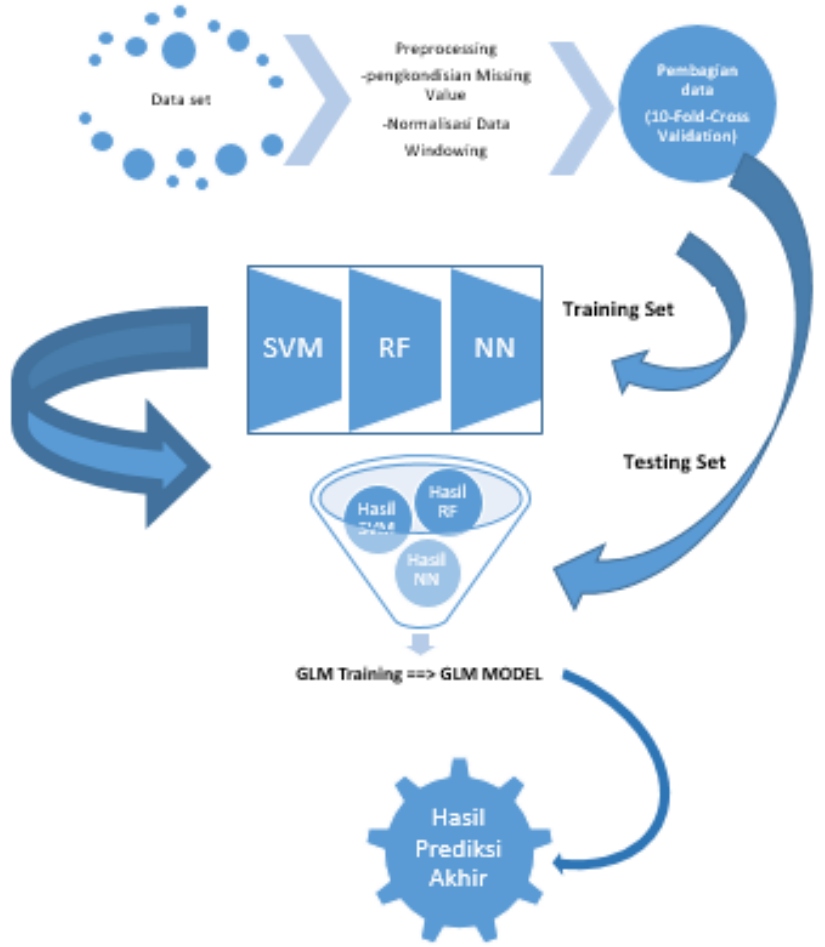

Gambar 7. Proses Stacking

\section{HASIL DAN PEMBAHASAN}

Berdasarkan penelitian terdahulu yang sudah dipaparkan sebelumnya, bahwasanya penggunaan stacking menghasilkan nilai akurasi yang lebih baik daripada penggunaan satu metode ataupun metode ensemble lainnya. Dan di dalam penelitian ini telah dilakukan proses prediksi dengan masing-masing algoritma untuk kemudian dibandingkan hasilnya dengan hasil stacking. Nilai akurasi yang digunakan adalah RMSE. Adapun hasil lengkapnya dapat terlihat di Tabel 1 .

Tabel 1. Perbandingan RMSE

\begin{tabular}{cc}
\hline Algoritma & RMSE \\
\hline SVM (S) & 0.702 \\
Random Forest (R) & 0.551 \\
Neural Network (N) & 0.655 \\
General Linier Model & 0.629 \\
Stacking (SRN+GLM) & 0.534 \\
\hline
\end{tabular}


Berdasarkan Tabel 1, terlihat bahawasanya jika menggunakan satu metode didapatkan akurasi SVM dalam memprediksi data runtun waktu laba BSI menempati urutan terakhir dengan RMSE 0.702 diikuti oleh NN di posisi ke dua dengan RMSE 0.655 dan GLM di posisi ke tiga dengan RMSE 0.629. Adapun Random Forest di posisi pertama dengan RMSE 0.551. Namun ketika diterapkan penggunaan Stacking maka memberikan hasil akurasi yang lebih baik dibandingkan pengguanan satu metode saja, dimana RMSE stacking dalam penelitian ini adalah 0.534.

\begin{tabular}{|l|l|l|l|l|l|}
\hline $\mathbf{A}$ & B & C & D & E & F \\
\hline & $0.534+l-0.142$ & $0.702+l-0.112$ & $0.551+l-0.151$ & $0.655+l-0.227$ & $0.629++-0.135$ \\
\hline $0.534+l-0.142$ & & 0.009 & 0.801 & 0.169 & 0.142 \\
\hline $0.702+l-0.112$ & & 0.021 & 0.567 & 0.206 \\
\hline $0.551+l-0.151$ & & & 0.241 & 0.238 \\
\hline $0.655+l-0.227$ & & & & & 0.758 \\
\hline $0.629+l-0.135$ & & & & & \\
\hline
\end{tabular}

\section{Gambar 8. Hasil Uji T-Test}

Proses T-Test adalah mengambil keluaran dari vektor kinerja sebagai masukan dan menguji perbedaan yang signifikan antara vektor kinerja dari setiap pasangan model yang ada. Gambar 7 menampilkan output dari operator TTest. Output menunjukkan akurasi rata-rata model sebagai nilai pertama di setiap baris serta nilai pertama di kolom B hingga F. Dengan tingkat signifikansi 0,05, disimpulkan bahwa model SVM memiliki tingkat kinerja yang berbeda secara signifikan yakni 0.009. Begitu juga dengan Random forest memiliki perbedaan yang signifikan yakni hasil 0.021. Sedangkan Neural Network dan Generalized Linier memiliki hasil > 0,05 sehingga dianggap tidak memiliki perbedaan yang signifikan.

\section{KESIMPULAN}

Peramalan jangka pendek yang akurat tentang laba sebuah bank, khususnya Bank Syariah Indonesia akan memberikan beberapa manfaat, baik secara ekonomi maupun pemerintahan. Karena Bank Syariah Indonesia menjadi satu-satunya Bank non-konvensional yang merupakan Bank Pemerintah. Peramalan dilakukan dengan mempertimbangkan data laba di masa lalu, yakni data historis. Peramalan jangka pendek bertujuan untuk memprediksi laba dalam waktu dekat. Penelitian ini telah menerapkan metode ensemble yang terdiri dari dua level, dimana mekanisme kerjanya menggabungkan hasil prediksi beberapa metode di level bawah untuk selanjutnya digunakan oleh algoritma di level atas untuk mencapai hasil prediksi baru yang biasanya akan lebih akurat. Penelitian ini menggunakan tiga metode di level bawah, yaitu Suport Vector Machine, Random Forest dan Neural Networks. Di lapisan atas menggunakan algoritma Generalized Linier Model. Peramalan yang menggunakan ensemble stacking terbukti lebih unggul dari hasil metode lainnya. Berdasarkan penelitian juga didapatkan bahwa metode tunggal seperti Random Forest, mampu menghasilkan akurasi yang lebih baik daripada metode tunggal lainnya. Untuk penelitian selanjutnya, akan dilakukan eksplorasi lebih lanjut dengan membandingkan metode ensemble lainnya, misalnya membandingkan stacking, boosting dan bagging. Selain itu, dapat pula menggunakan data set lainnya, seperti data set penyintas Covid 19 .

\section{REFERENCES}

[1] S. J. Taylor, B. Letham, S. J. Taylor, and B. Letham, "Forecasting at Scale," vol. 1305, no. October, 2017, doi: 10.1080/00031305.2017.1380080.

[2] R. J. Hyndman and G. Athanasopoulos, Forecasting : Principles and Practice. 2018.

[3] T. Ahmad and H. Chen, "A review on machine learning forecasting growth trends and their real-time applications in different energy systems,” Sustain. Cities Soc., vol. 54, p. 102010, 2020, doi: 10.1016/j.scs.2019.102010.

[4] R. S. Sengar and F. Ahmed, "Review on Trends in Machine Learning Applied to Demand \& Sales Forecasting Related papers," Smart Moves J. IJOSCIENCE, vol. 5, no. 12, 2019.

[5] J. F. Rendon-sanchez and L. M. De Menezes, “PT,” Eur. J. Oper. Res., 2018, doi: 10.1016/j.ejor.2018.12.013.

[6] C. M. Cheung, R. Kannan, and V. K. Prasanna, "Temporal Ensemble Learning of Univariate Methods for Short Term Load Forecasting," 2018.

[7] E. Gulay, "Forecasting the total electricity production in South Africa: Comparative analysis to improve the predictive modelling accuracy," AIMS Energy, vol. 7, no. 1, pp. 88-110, 2019, doi: 10.3934/energy.2019.1.88.

[8] T. A. Munna, M. M. Alam, S. M. Allayear, K. Sarker, S. Joly, and F. Ara, Prediction Model for Prevalence of Type-2 Diabetes Complications with ANN Approach Combining with K-Fold Cross Validation and K-Means Clustering, vol. 1. Springer International Publishing.

[9] C. M. Liapis, A. Karanikola, and S. Kotsiantis, "An ensemble forecasting method using univariate time series COVID-19 data," in ACM International Conference Proceeding Series, Nov. 2020, pp. 50-52, doi: 10.1145/3437120.3437273.

[10] A. M. Awajan, M. T. Ismail, and S. Al Wadi, "Improving forecasting accuracy for stock market data using emd-hw bagging," PLoS One, vol. 13, no. 7, Jul. 2018, doi: 10.1371/journal.pone.0199582. 
[11] T. Phan, "Comparative Study on Univariate Forecasting Methods for Meteorological Time Series," pp. 2380-2384, 2018.

[12] X. Wang, K. Smith-miles, and R. Hyndman, "Neurocomputing Rule induction for forecasting method selection: Metalearning the characteristics of univariate time series," vol. 72, pp. 2581-2594, 2009, doi: 10.1016/j.neucom.2008.10.017.

[13] Z. Shen, Y. Zhang, J. Lu, J. Xu, and G. Xiao, "A novel Time Series Forecasting Model with Deep Learning," Neurocomputing, 2019, doi: 10.1016/j.neucom.2018.12.084.

[14] R. Chuentawat and Y. Kan-ngan, "The Comparison of PM2 . 5 forecasting methods in the form of multivariate and univariate time series based on Support Vector Machine and Genetic Algorithm," 2018 15th Int. Conf. Electr. Eng. Comput. Telecommun. Inf. Technol., pp. 572-575, 2018.

[15] S. Makridakis, E. Spiliotis, and V. Assimakopoulos, "Statistical and Machine Learning forecasting methods: Concerns and ways forward," PLoS One, vol. 13, no. 3, pp. 1-26, 2018, doi: 10.1371/journal.pone.0194889.

[16] A. Cecaj, M. Lippi, M. Mamei, and F. Zambonelli, "Comparing deep learning and statistical methods in forecasting crowd distribution from aggregated mobile phone data," Appl. Sci., vol. 10, no. 18, 2020, doi: 10.3390/APP10186580.

[17] M. Silfiani and Suhartono, "Aplikasi Metode Ensembel untuk Peramalan Inflasi di Indonesia," J. Sains dan Seni ITS, vol. 1, no. 1, pp. 171-175, 2012.

[18] S. Lee, B. KC, and J. Y. Choeh, "Comparing performance of ensemble methods in predicting movie box office revenue," Heliyon, vol. 6, no. 6, Jun. 2020, doi: 10.1016/j.heliyon.2020.e04260.

[19] A. Doudkin, Y. Marushko, J. Owsinski, and T. Pawlowski, "Spacecraft Telemetry Time Series Forecasting with Ensembles of Neural Networks," Proc. 2019 10th IEEE Int. Conf. Intell. Data Acquis. Adv. Comput. Syst. Technol. Appl. IDAACS 2019, vol. 2, no. 3, pp. 752-756, 2019, doi: 10.1109/IDAACS.2019.8924252.

[20] S. Lahmiri, R. G. Saade, D. Morin, and F. Nebebe, "An Artificial Neural Networks Based Ensemble System to Forecast Bitcoin Daily Trading Volume," Proc. 2020 5th Int. Conf. Cloud Comput. Artif. Intell. Technol. Appl. CloudTech 2020, vol. i, no. January 2009, pp. 1-4, 2020, doi: 10.1109/CloudTech49835.2020.9365913.

[21] A. S. Khwaja, A. Anpalagan, M. Naeem, and B. Venkatesh, "Joint bagged-boosted artificial neural networks: Using ensemble machine learning to improve short-term electricity load forecasting," Electr. Power Syst. Res., vol. 179, no. October 2019, p. 106080, 2020, doi: 10.1016/j.epsr.2019.106080.

[22] F. Divina, A. Gilson, F. G. Vela, M. G. Torres, and J. F. Torres, "Stacking Ensemble Learning for Short-Term Electricity Consumption Forecasting," Energies, vol. 11, no. 4, pp. 1-31, 2018, doi: 10.3390/en11040949.

[23] M. Jiang, J. Liu, and L. Zhang, "An improved Stacking framework for stock index prediction by leveraging tree-based ensemble models and deep learning algorithms," Physica A, p. 122272, 2019, doi: 10.1016/j.physa.2019.122272.

[24] Z. Ma, P. Wang, Z. Gao, R. Wang, and K. Khalighi, "Ensemble of machine learning algorithms using the stacked generalization approach to estimate the warfarin dose_Enhanced Reader.pdf," PLoS One, 2018.

[25] I. Izonin and R. Tkachenko, "Stacking-based GRNN-SGTM Ensemble Model for Prediction Tasks," pp. 326-330, 2021.

[26] B. Zhai and J. Chen, "Science of the Total Environment Development of a stacked ensemble model for forecasting and analyzing daily average PM 2 . 5 concentrations in Beijing, China," Sci. Total Environ., vol. 635, pp. 644-658, 2018, doi: 10.1016/j.scitotenv.2018.04.040.

[27] N. Fahana, S. Aisyah, C. W. Sitorus, P. Agita, and M. R. Lubis, "Analisis Jaringan Syaraf Tiruan Dalam Memprediksi Laba / Rugi Bank Umum Syariah di Indonesia,” pp. 524-529, 2019.

[28] W. Wiyono, "Dampak Merger 3 (Tiga) Bank Syariah Bumn Terhadap Perkembangan Ekonomi Syariah," Cakrawala Huk., vol. XII, no. 01, pp. 95-110, 2016, [Online]. Available: http://e-journal.unwiku.ac.id/hukum/index.php/CH/article/view/142.

[29] P. Xue and Y. Lei, "Net Profit Forecast Based on Improved Support Vector Machine," in 2021 IEEE International Conference on Artificial Intelligence and Computer Applications (ICAICA), 2021, pp. 692-696, doi: 10.1109/ICAICA52286.2021.9497965.

[30] Y. Zhang, M. Zhong, N. Geng, and Y. Jiang, "Forecasting electric vehicles sales with univariate and multivariate time series models: The case of China," PLoS One, vol. 12, no. 5, pp. 1-15, 2017, doi: 10.1371/journal.pone.0176729.

[31] T. Jilani, G. Housley, G. Figueredo, P. Tang, J. Hatton, and D. Shaw, "International Journal of Medical Informatics Short and Long term predictions of Hospital emergency department attendances," Int. J. Med. Inform., vol. 129, no. November 2018, pp. 167-174, 2019, doi: 10.1016/j.ijmedinf.2019.05.011. 